\title{
Robert Ptak
}

\section{Kościół w służbie Królestwa Bożego : trynitarny i eklezjologiczny wymiar zbawienia człowieka}

Prawo Kanoniczne : kwartalnik prawno-historyczny 50/1-2, 213-229

2007

Artykuł został zdigitalizowany i opracowany do udostępnienia w internecie przez Muzeum Historii Polski w ramach prac podejmowanych na rzecz zapewnienia otwartego, powszechnego i trwałego dostępu do polskiego dorobku naukowego i kulturalnego. Artykuł jest umieszczony w kolekcji cyfrowej bazhum.muzhp.pl, gromadzącej zawartość polskich czasopism humanistycznych i społecznych.

Tekst jest udostępniony do wykorzystania w ramach dozwolonego użytku. 
Prawo Kanoniczne

$50(2007) \mathrm{nr} 1-2$

KS. ROBERT PTAK SCJ

Uniwersytet Kardynała Stefana Wyszyńskiego w Warszawie

\section{KOŚCIÓŁ W SŁUŻBIE KRÓLESTWA BOŻEGO TRYNITARNY I EKLEZJOLOGICZNY WYMIAR ZBAWIENIA CZEOWIEKA}

Treść: Wstęp. - 1. Trynitarne pochodzenie Kościoła. 2. Trynitarna misja Kościola. 3. Zbawczy związek Chrystusa z królestwem i Kościołem. 4. Kościól - powszechny sakrament zbawienia. 5. Służebna misja Kościoła. - Zakończenie.

\section{Wstęp}

Idea królestwa Bożego, stanowiąca centrum misji Jezusa Chrystusa, odzwierciedla powszechny charakter zbawienia, którego źródłem jest Trójca Święta. Kościół upamiętnia i głosi Chrystusową Ewangelię o królestwie Bożym, w którym upatruje swój cel i swoje wypełnienie u kresu historii. Zbawienie czlowieka, które ma charakter trynitarny, dokonuje się w Kościele i poprzez jego posłannictwo i wielowymiarową posługę. Analizując zagadnienie tej służebnej roli Kościoła, zostanie najpierw ukazane trynitarne pochodzenie Kościoła (1) i jego trynitarna misja (2); następnie uwypuklony zostanie zbawczy związek Chrystusa zarówno z królestwem, jak i Kościołem (3). Ważne w tej analizie będzie spojrzenie na Kościół jako powszechny sakrament zbawienia (4) oraz syntetyczne uwydatnienie niektórych aspektów służebnej misji Kościoła (5). Celem tak przeprowadzonej analizy będzie zwrócenie uwagi na te elementy, które wskazują na powszechny wymiar zbawienia realizowanego przez Trójcę Świętą w Kościele i poprzez Kościół. Pomocą $w$ ich właściwym odczytaniu będą wybrane dokumenty Magisterium Kościoła z drugiej połowy XX wieku.

\section{Trynitarne pochodzenie Kościoła}

Sobór Watykański II, wnikając w istotę Kościoła, sięgnął do eklezjologii św. Pawła, który w Liście do Efezjan używa określenia mi- 
sterium. Wskazuje ono na tajemniczy plan zbawienia i uświęcenia człowieka przez Trójce Świętą, która objawia się jako communio Ojca i Syna i Ducha Swiętego. Bóg w swoim wewnętrznym życiu „bytuje na sposób daru” i jest cały ukierunkowany na relacje wewnątrztrynitarne. To immanentne życie Boga Trójosobowego otwiera się również na rzeczywistość poza Nim samym - na Jego stworzenia. Owocem tego zbawczego udzielania się Boga jest Kościól, w którym realizuje się zbawcze misterium Ojca, wyrażone w misji Syna i Ducha Świętego. Posłannictwo Kościoła ukazuje zatem człowiekowi i światu trynitarne Oblicze Boga?

Konstytucja Lumen gentium, wskazując na najgłębsze źródła pochodzenia Kościoła, mówi o zbawczym zamyśle Przedwiecznego Ojca, który „na skutek najzupełniej wolnego i tajemnego zamysłu swej mądrości i dobroci, stworzył świat cały, a ludzi postanowił wynieść do uczestnictwa w życiu Bożym"”. Według tego zamysłu człowiek, stworzony na obraz i podobieństwo Boże, został przeznaczony do wyjątkowej relacji ze swoim Stwórcą, do uczestnictwa we wspólnocie Trójcy Świętej i odkrywania tajemnicy wewnętrznej komunii Osób Boskich. Objawienie tego „tajemniczego planu, ukrytego przed wiekami w Bogu, Stwórcy wszechrzeczy" (Ef 3,9) implikuje istnienie Kościoła, mającego swoje źródło w tym samym odwiecznym planie zbawienia. Wypływa on ze źródła miłości, czyli z milości Ojca, który wszystkich ludzi wybranych przed wiekami, przewidział i przeznaczyl, aby stali się podobni do Jego Syna, pierworodnego między wielu braćmi (por. Rz 8,29) ${ }^{4}$.

Początek Kościoła, według Lumen gentium, wiąże się z postanowieniem przywrócenia utraconej przez grzech więzi człowieka z Bogiem, z odzyskaniem przez niego życia Bożego. Można więc mówić o preegzystencji Kościoła, czyli logicznym jego pierwszeństwie wobec calego stworzenia w odwiecznym planie Boga i to nie

\footnotetext{
' J a n Paw et I I, Encyklika o Duchu Świętym w zyciu Kościola i świata Dominum et Vivificantem, 10. [W:] Encykliki Ojca Świętego Jana Pawla II, t. I, Wydawnictwo św. Stanisława B. M. Archidiecezji Krakowskiej i Wydawnictwo M, Kraków 1996 (Dalej skrót: DetV).

${ }^{2}$ Por. W. K a s p e r, Bóg Jezusa Chrystusa, Wydawnictwo Księgarni Archidiecezjalnej, Wrocław 1996, s. 389-390.

${ }^{3}$ Konstytucja dogmatyczna o Kościele Lumen gentium, 2. [W:] Sobór Watykański II. Konstytucje, dekrety, deklaracje, Wydawnictwo Pallottinum, Poznań 1967, wydanie III (dalej skrót: KK).

${ }^{4}$ Por. KK 2.
} 
tylko $\mathrm{z}$ racji swego ostatecznego celu i kształtu, ale również z racji swego pozaczasowego początku. W ten sposób Kościół włączony jest zarówno w odwieczny plan zbawienia każdego człowieka, jak i w tajemnicze działanie Boże realizujące ten plan w dziejach ludzkościs. Zbawcze działanie Trójcy Swiętej, jako Wspólnoty Osób Boskich, posiada swoje odzwierciedlenie we wspólnotowym wymiarze realizacji odwiecznego planu. Spodobało się bowiem Bogu powołać ludzi do uczestnictwa w swoim życiu ,nie pojedynczo (...), z wykluczeniem wszelkiej wzajemnej więzi, lecz do utworzenia $\mathrm{z}$ nich ludu, w którym rozproszone Jego dzieci zgromadziłyby się w jedno"'.

Odwieczna wola zbawcza Boga Ojca realizuje się w pełni czasów poprzez misję Syna, w którym wybrał każdego człowieka przed stworzeniem świata i obdarzył go przybranym synostwem, by w Nim odnowić wszystko (por. Ef 1,4-5, 10). Jezus Chrystus, Słowo Wcielone, jest Synem wspólistotnym Ojcu, zjednoczonym z Nim w Bóstwie (por. J 10,30), który pragnie pojednać człowieka z Ojcem i przywrócić mu utracone dziecięctwo Boże. Misja Jezusa ma swoje źródlo w trynitarnej komunii Osób Boskich, gdyż Jego pokarmem jest wypełnić wolę Tego, który Go posłał (por. J 4,34). Konstytucja Lumen gentium, nawiązując do genezy Kościoła, wyraźnie wskazuje na misję Jezusa, który wypełniając wolę Ojca „zapoczątkował królestwo niebieskie na ziemi i objawił nam tajemnicę Ojca, a posłuszeństwem swym dokonal odkupienia. Kościół, czyli królestwo Chrystusowe już teraz obecne w tajemnicy, dzięki mocy Bożej rośnie w sposób widzialny w świecie"

Podobnie jak w centrum zamiarów Ojca jest misja Syna, tak w centrum przesłania Syna jest głoszenie zbawczego orędzia, które poprzez obraz królestwa Bożego tworzy wspólnotę ludzi na nowo zjednoczonych z Bogiem Ojcem. Znakiem tego zjednoczenia jest ofiara Jezusa na krzyżu, dzięki której przyciąga On wszystkich do siebie (por. J 12,32). Na krzyżu, z otwartego Serca Zbawiciela, wypływa krew i woda, dając początek Kościołowi, jako wspólnocie lu-

\footnotetext{
${ }^{s}$ Por. J. B ru dz, Misterium Kościola, [w:] „Idee przewodnie Soborowej Konstytucji o Kościele”, PTT Kraków 1971, s. 47.

${ }^{6}$ Dekret o dzialalności misyjnej Kościola Ad gentes, 2. [W:] Sobór Watykański II. Konstytucje, dekrety, deklaracje, Wydawnictwo Pallottinum, Poznań 1967, wydanie III (dalej skrót: DM).

${ }^{7}$ KK 3.
} 
dzi pojednanych z Bogiem. W ofierze Jezusa Chrystusa dopełnia się Jego zbawcze posłannictwo, by doprowadzić do prawdziwej komunii tych, których dał Mu Ojciec (por. J 17,6). Rzeczywistość ta, jako owoc odkupieńczej ofiary Syna, przekracza wymiar personalny, przyjmując znamiona wspólnotowe i uniwersalne. W Chrystusie wszyscy stają się nowym stworzeniem (por. 2Kor 5,17 ) i w Nim rodzi się nowy człowiek według Boga, w sprawiedliwości i prawdziwej świętości (por. Ef 4,24). Komunia wewnątrztrynitarna znajduje zatem swoje odzwierciedlenie w misji Syna Bożego, który powoluje do życia Kościól, jako znak i narzędzie wewnętrznego zjednoczenia z Bogiem i jedności całego rodzaju ludzkiego'.

Misja Syna, zakorzeniona w zbawczej woli Ojca, jest integralnie złączona z posłannictwem Ducha Świętego. Jedność zbawczej ekonomii Jezusa Chrystusa i Ducha Świętego widoczna jest na każdym etapie realizacji zbawczego planu Ojca. Widzimy to zarówno poprzez obecność Ducha Swiętego w tajemnicach ziemskiej misji Chrystusa, jak i po Jego wniebowstąpieniu. Misja Ducha Świętego jest wpisana w posłannictwo Syna w pierwszym rzędzie jako dar od Ojca. To za sprawą Ducha Świętego wypełniła się tajemnica wcielenia (por. Łk 1,35), a cała publiczna działalność Chrystusa dokonywała się w mocy tegoż Ducha (por. Łk 4,18-21). W momencie zaś, gdy „dopełniło się dzieło, którego wykonanie Ojciec powierzył Synowi na ziemi (por. J 17,4), zesłany zostal w dzień Zielonych Swiąt Duch Święty, aby Kościól ustawicznie uświęcal i aby w ten sposób wierzący mieli przez Chrystusa w jednym Duchu dostęp do Ojca (por. Ef 2,18)"10. Misją więc Ducha Świętego stało się dopełnienie dzieła Syna i doprowadzenie do końca historii zbawienia.

Bóg Trójjedyny poprzez dar Ducha Świętego otwiera się w nowy sposób na czlowieka, którego pragnie wprowadzić w nadprzyrodzony wymiar życia zjednoczonego z Boską tajemnicą. To dzięki Duchowi Świętemu Ojciec i Syn przychodzą do człowieka i czynią u niego mieszkanie (por. J 14,23). Pod działaniem tego samego Ducha człowiek podejmuje wysiłek przybliżania się do swojego ostatecznego przeznaczenia, które znajduje się w Bogu. Kościół został określony w Lumen gentium sakramentem, czyli znakiem i na-

\footnotetext{
${ }^{8}$ Por. W. Kas per, Jezus Chrystus, Pax, Warszawa 1983, s. 121.

${ }^{9}$ Por. KK 1 .

${ }^{10} \mathrm{KK} 4$.
} 
rzędziem tego przybliżania się do Boga całego rodzaju ludzkiego. Kościół więc mocą Ducha Świętego przenika ziemskie pielgrzymowanie człowieka i prowadzi go do komunii z Bogiem ${ }^{11}$.

\section{Trynitarna misja Kościola}

II Sobór Watykański, określając naturę Kościoła, wskazał na jego fundamentalny wymiar wyrażający się w poslannictwie i misji otrzymanej od samego Boga. Kościól bierze swój początek z posłania Syna i z posłania Ducha Świętego, a plan ten wypływa ze źródła miłości, czyli z miłości Boga Ojca ${ }^{12}$. Kościół jako missio ma źródło w Ojcu, który w swojej dobroci i miłości stworzył świat, a na nim ludzi i pragnie, by wszyscy oni zostali zbawieni i doszli do poznania prawdy (por. 1Tm 2,3-4). Stąd też, gdy nadeszla pelnia czasów, Ojciec, którego serce jest otwarte dla wszystkich, poprzez Syna w Duchu Świętym ustanawia powszechny kult (por. J 4,21-23). Wolą Ojca staje się również misja zlecona przez Jezusa swoim uczniom, by przeszli od królestwa obejmującego tylko $\mathrm{Na}-$ ród Wybrany do królestwa Bożego ogarniającego wszystkie narody. Idąc po tej linii, Kościół zbudowany na fundamencie apostolów wylania się z powszechnego serca Ojca i ukazuje Jego ojcostwo wobec całej ludzkości. Jest to ojcostwo wypełnione milością najpierw tą immanentną wobec Syna i Ducha Świętego, a poprzez zbawcze działanie angażujące całą Trójcę Świętą obejmującą również całą ludzkośćcín

Kościól ukazany jest w Konstytucji Lumen gentium nie tylko jako rzeczywistość widzialna, lecz w głównej mierze jako misterium możliwe do poznania jedynie dzięki objawieniu Bożemu i nadprzyrodzonej wierze w tajemnicę Trójcy Świętej i tajemnicę wcielenia. W świetle tych tajemnic Kościół staje się sakramentem zbawienia, w którym i poprzez który zgodnie z odwiecznym planem Boga Ojca, nieustannie przepływa nadprzyrodzone życie Boże. To życie udzielane jest ludziom dla ich zbawienia, które zostało wysłużone im przez Syna w posłuszeństwie Ojcu i pełnej realizacji zbawczej misji w Misterium Paschalnym. Duch Swięty zstępując na Kościół zaszczepia to Misterium w ludzkie serca i doprowadza

\footnotetext{
"Por. DetV 64.

${ }_{12}^{12}$ Por. DM 2.

${ }^{13}$ Por. S. G r ze ch ow i a k, Kosciele, kim jesteś?, Gaudentinum. Guiezno 2002, s. 191.
} 
je do pełni rozwoju. W ten sposób cała ludzkość przez pośrednictwo Kościoła, w którym realizuje się zarówno misja Jezusa Chrystusa jak i Ducha Świętego, zdąża do Ojca Przedwiecznego, początku i źródła wszelkiego życia. Taka rola i powołanie Kościoła czyni z niego prawdziwe światto narodów, widzialny znak zjednoczenia ludzi z Bogiem i jedności między sobą oraz nadaje jego misji znamiona trynitarne $e^{14}$.

Ta trynitarna misja Kościoła, wynikająca $z$ woli Boga w Trójcy Świętej, ma na celu realizację powszechnego planu zbawczego. Wezwanie Jezusa skierowane do uczniów po swoim zmartwychwstaniu, określane jako nakaz misyjny: „Idźcie więc i nauczajcie wszystkie narody" (Mt 28,19), zawiera w sobie trynitarną formulę chrzcielną: „udzielając im chrztu w imię Ojca i Syna i Ducha Świętego" (Mt 28,19). Formuła ta odzwierciedla wewnętrzną tajemnicę Boga, Jego życie, wyrażające się w Boskiej Jedności Trójcy. Trynitarna formula chrzcielna wyraża również życiodajną moc sakramentu, który sprawia uczestnictwo w życiu Trójjedynego Boga, ponieważ daje laskę uświęcającą jako nadprzyrodzony dar dla człowieka. Przez nią czlowiek zostaje powołany i uzdolniony do uczestnictwa w niewypowiedzianym zyciu Boga ${ }^{15}$.

Doświadczenie Kościoła dotyczące jego udziału w realizacji zbawczej woli Boga i trynitarnym objawieniu się Osób Boskich, nadaje mu szczególną rolę jako łącznika Boskiej rzeczywistości Trójcy Przenajświętszej z rzeczywistością ludzką. W tajemnicy Pięćdziesiątnicy zostal wyzwolony przez Ducha Swiętego trynitarny dynamizm, dzięki któremu Kościól został wyposażony w Boską moc, nieustannie podtrzymywaną w sercach wiernych jako Miłość Ojca i Syna. Posłannictwo Kościoła, ubogaconego darami swego Założyciela i wiernie dochowującego jego „przykazań miłości, pokory i wyrzeczenia, otrzymuje posłannictwo głoszenia i krzewienia królestwa Chrystusowego i Bożego wśród wszystkich narodów"16.

\section{Zbawczy związek Chrystusa z królestwem i Kościolem}

Wśród wielu trudności, jakie niesie ze sobą współczesna problematyka religii i jej zbawczej roli, pluralizmu religijnego oraz global-

\footnotetext{
${ }^{14}$ Por. J. Brudz, Misterium Kościola, dz. cyt., s. 62.

${ }^{15}$ Por. DetV 9.

${ }^{16}$ KK 5.
} 
nej komunikacji społecznej i kulturowej, szczególnie kontrowersyjna jawi się sprawa pełnego i ostatecznego objawienia się Boga w Jezusie Chrystusie oraz kwestia pełni zbawczych środków przekazanych przez Jezusa Chrystusa Kościołowi. W gorącą dyskusję wokół wspomnianych tematów wpisuje się Magisterium Kościoła wraz z Deklaracją Dominus Iesus ${ }^{17}$, która koncentruje się na zagadnieniu jedyności i powszechności zbawczej Jezusa Chrystusa i Kościoła. Największym zagrożeniem dla zbawczego posłannictwa Kościoła we współczesnych czasach są teorie relatywistyczne, które chcą usprawiedliwić pluralizm religijny nie tylko de facto, lecz także de iure, czyli jako zasadę ${ }^{18}$. Wspomniany relatywizm poddaje w wątpliwość m.in. takie prawdy, jak: ostateczny i całkowity charakter Objawienia Jezusa Chrystusa, jedyność i zbawcza powszechność tajemnicy Jezusa Chrystusa, czy też nierozdzielność - mimo odrębności - królestwa Bożego, królestwa Chrystusa i Kościoła ${ }^{19}$. Konkretnym odbiciem takich tendencji jest odniesienie do osoby Jezusa Chrystusa, która staje się znakiem sprzeciwu i punktem, który polaryzuje różnorodne nurty myślowe. A skoro tak, to wciąga w swoją orbitę również zagadnienia dotyczące królestwa i Kościoła ${ }^{20}$.

Posłannictwo Kościoła polega na głoszeniu i krzewieniu królestwa Chrystusowego i Bożego wśród wszystkich narodów, co daje mu tytuł, by stanowić zalążek oraz zaczątek tego królestwa na zie$\mathrm{mi}^{21}$. Taki charakter Kościoła wypływa z jego sakramentalnej natury. Kościół w nauczaniu II Soboru Watykańskiego jest bowiem powszechnym sakramentem zbawienia, gdyż jest ,jeden” i ,jedyny" w swej zbawczo-pośredniczącej roli, podobnie jak Chrystus jest jedynym pośrednikiem pomiędzy Bogiem i ludźmi (por. 1Tm 2,5). Dlatego jedyność Jezusa wiąże się nierozdzielnie $z$ jedynością Kościoła. Kościół staje się zatem prawdziwym znakiem i narzędziem wewnętrznego zjednoczenia $z$ Bogiem $\mathrm{i}$ jedności całego rodzaju ludzkiego. Staje się poprzez to również znakiem i narzędziem kró-

\footnotetext{
${ }^{17}$ Kongregacja Nauki Wiary, Deklaracja Dominus Iesus o jedyności i powszechności zbawczej Jezusa Chrystusa i Kościola, TUM Wrocław 2000 (dalej skrót: DI).

${ }^{18}$ Por. J. Ratzinge r, Kontekst i znaczenie Dokumentu, "LOsservatore Romano" $11-12(228) 2000$.

${ }^{19}$ Por. DI 4.

${ }^{20}$ Por. H. Sewe ryniak, Święty Kościól powszedni, Biblioteka „Więzi”, Warszawa 1999, s. 31.

${ }^{21}$ Por. KK 5.
} 
lestwa Bożego, którego głoszenie i ustanawianie należało do istoty ziemskiej misji Jezusa Chrystusa ${ }^{22}$.

Kościół stanowi również wspólnotę powołaną do istnienia w jedności Ojca i Syna i Ducha Świętego, dlatego - jak określa to II Sobór Watykański - staje się on „królestwem Chrystusowym już teraz obecnym w tajemnicy"23. To misterium królestwa, a także jego niepełność i brak dojrzałości, o czym mówią wyrażenia zalążek i zaczqtek wskazują na jego wymiar eschatologiczny. Świadczy to o konieczności spojrzenia na rzeczywistość królestwa w perspektywie dynamizmu stawania się, a więc zarówno obecności w czasie i przestrzeni (,już"), jak i oczekiwania na jego pełne objawienie się na końcu czasów (,jeszcze nie”). Prawdziwe odniesienie Kościoła do królestwa realizuje się w wymiarze eschatologicznym, gdyż Kościół jest królestwem Bożym, albowiem Chrystus pokonał świat i w Nim znajduje się całe nasze zbawienie, i nie jest królestwem Bożym, ponieważ ma je głosić aż do Jego ostatecznego przyjścia ${ }^{24}$.

Wymiar eschatologiczny i misteryjny królestwa tworzy i kształtuje wewnętrzną więź pomiędzy Chrystusem i Kościołem. Trzeba stanowczo podkreślić, iż królestwo Boże, które znamy z Objawienia, nie może zostać odłączone ani od Chrystusa, ani od Kościoła. Pozbawienie bowiem królestwa wymiaru chrystologicznego odcina je od swojego korzenia. Bez Chrystusa królestwo przybiera kształt czysto ludzki i doczesny, staje się swoistą ideologią i ogranicza się do wymiaru socjologiczno-politycznego. Oderwanie królestwa od Jezusa prowadzi również w konsekwencji do wypaczenia tożsamości Chrystusa - przestaje On jawić się jako Pan, któremu wszystko ma być poddane (por. 1Kor 15,27)

Podobnie nie można zdecydowanie rozdzielać królestwa i Kościoła, stawiając te rzeczywistości na przeciwnych biegunach. To prawda, że Kościół nie jest celem samym w sobie, gdyż stanowi zalążek wzrostu, znak obecności i narzędzie królestwa Bożego. Kościół jest więc przyporządkowany królestwu, ale posiada wła-

\footnotetext{
${ }^{22}$ Por. Ch. Sc hö n b o r n, Dominus Iesus $w$ dialogu międzyreligijnym, „Communio” 1 (2002), s. 113.

${ }^{23} \mathrm{KK} 3$.

${ }^{24}$ Por. J. R. Armogate, Oblubienica Chrystusa i Matka wierzacych, „Communio" 1 (2002), s. 107.

${ }^{25}$ Por. G. Se gall a, Samopojmowanie Jezusa jako pośrednika Boga Ojca i Jego królestwa, „Communio" 1 (2002), ss. 62-70.
} 
sną tożsamość i cieszy się autonomią zarówno wobec Chrystusa, jak i królestwa ${ }^{26}$. Deklaracja Dominus Iesus podkreśla, że królestwo Boże w aspekcie historycznym nie jest tożsame z Kościołem jako rzeczywistością widzialną i społeczną. Nie jest bowiem wykluczone działanie Chrystusa i Ducha Świętego poza widzialnymi granicami Kościoła ${ }^{27}$. Oznacza to, że rozwój królestwa Bożego, a poprzez nie realizacja zbawczego planu Boga, dotyczy wszystkich ludzi, społeczeństw i całego świata ${ }^{28}$. Przyczyniać się do rozwijania rzeczywistości królestwa, to służyć budowie dobra, popierać Boży dynamizm obecny w ludzkiej historii i pracować nad wyzwoleniem od zła we wszystkich jego formach. Tak pojmowane królestwo Boże staje się ,wyrazem i urzeczywistnieniem zbawczego planu w całej jego pełni"'s.

Deklaracja Dominus Iesus w swojej refleksji nad relacjami zachodzącymi pomiędzy królestwem Bożym, królestwem Chrystusowym i Kościołem dotyka niepokojącego współcześnie zjawiska jednostronnego akcentowania wybranych aspektów tych relacji. Mamy więc do czynienia $\mathrm{z}$ przesadnym naciskiem na królestwo i sytuowaniem go w centrum, w wyniku czego główne miejsce Kościoła, Chrystusa i Boga zostaje zastąpione królestwem, jako wspólnym zadaniem wszystkich religii, w którym wszystkie mogą spotkać się ze sobą ${ }^{30}$ W takim ujęciu Kościół postrzegany jest wyłącznie jako tzw. „Kościól dla drugich”, a więc nie myślący o własnej tożsamości i całkowicie zajęty dawaniem świadectwa i służeniem królestwu. W takim rozumieniu królestwa Kościół zostaje zepchnięty na margines, jest niedoceniany lub uważany za zwykły znak, zresztą nie pozbawiony wieloznaczności ${ }^{31}$.

Niewłaściwe akcentowanie relacji między królestwem Bożym, królestwem Chrystusowym i Kościołem znajduje również swoje od-

\footnotetext{
${ }^{26}$ Por. DI 18.

${ }^{27}$ Por. DI 19.

${ }^{28}$ W tym rozwoju królestwa szczególne miejsce zajmuje obecnie kwestia dialogu międzyreligijnego. W świetle Dominus Iesus tzw. pluralistyczna teologia religii chcialaby wyrzeczenia się chrześcijańskiego roszczenia do bycia „prawdziwą religią", wprowadzenia Jezusa do panteonu wielkich osobistości religijnych, a w konsekwencji odrzucenia Jezusa jako Mesjasza, Syna Bożego i jedynego zbawiciela świata. Por. Ch. S c h ö n bor n, Dominus lesus $w$ dialogu międzyreligijnym, „Communio” 1 (2002), s. 117.

${ }^{29}$ DI 19.

${ }^{30}$ Por. J. Ratzing e r, Chrystus, wiara a wyzwanie kultur, „Communio” 1 (2002), s. 88.

${ }^{31}$ Por. DI 19.
} 
niesienie do osoby Jezusa Chrystusa. Mamy do czynienia z przemilczaniem Jego roli w ustanowieniu królestwa i realizacji zbawczego planu Boga. Tak postrzegane królestwo opiera się jedynie na teocentryzmie. W ten sposób różne ludy, kultury i religie ${ }^{32}$ mogą jedynie odnaleźć się w jednej Boskiej rzeczywistości, niezależnie jak ją nazwiemy. To zaś daje pierwszeństwo tajemnicy stworzenia, w której odzwierciedla się różnorodność kultur i wierzeń, pomijając jednak tajemnicę odkupienia. W odpowiedzi Deklaracja potwierdza wiare Kościoła w to, że Jezus Chrystus objawia nam rzeczywiście i calkowicie prawdę Bożą i że Kościół, kierowany przez Ducha Świętego, przekazuje światu, razem z tą prawdą, Boże zbawienie ${ }^{33}$.

\section{Kościól - powszechny sakrament zbawienia}

Zbawcza obecność i działanie Jezusa Chrystusa, wyrażane poprzez ideę królestwa Bożego, znajduje swoją kontynuację w tajemnicy Kościoła, który zostal przez Niego założony i ciągle jest ożywiany obecnością Ducha Świętego. Spotkanie człowieka z jedynym i powszechnym zbawicielem Jezusem Chrystusem dokonuje się zasadniczo we wspólnocie kościelnej. Staje się ona miejscem zbawienia nie tylko dla chrześcijan, ale również dla wszystkich ludzi, którzy szczerym sercem szukają Boga i, starając się żyć zgodnie z nakazami swego sumienia, wypełniają wolę Bożą ${ }^{34}$. Kościól bowiem nie jest zwiastunem potępienia, lecz znakiem i narzędziem zbawienia powszechnego, stanowiąc na ziemi zalążek oraz zaczątek królestwa zapoczątkowanego przez Chrystusa, który jest ostatecznym gwarantem zbawienia ${ }^{35}$. Na Nim opiera się zbawcza konieczność Kościo-

${ }^{32}$ Zagadnienie kultury, inkulturacji i spotkania kultur w perspektywie dialogu chrześcijaństwa $\mathrm{z}$ innymi religiami w kontekście dyskusji wokół Dominus Iesus omawia m.in. J. R a $\mathrm{z}$ ing e r, Chrystus, wiara a wyzwanie kultur, art. cyt., ss. 77-97.

${ }^{33}$ Por. J. A. Ma rt in e z Ca min o, Deklaracja Dominus Iesus w samym centrum Jubileuszu Roku 2000: wobec najpoważniejszego problemu naszych czasów, „Communio” 1 (2002), s. 26.

${ }^{34}$ Por. KK 16.

${ }^{35}$ Zasada extra Ecclesiam nulla salus przyjęta przez II Sobór Watykański (KK 14: „Kóściól konieczny jest do zbawienia”) odnosi się wyraźnie do katolików i ogranicza jej obowiązywanie do tych, którzy wiedzą o konieczności Kościola do zbawienia. Zasada ta, połączona $z$ bardziej ogólną extra Christum nulla salus, nie stoi w sprzeczności z powołaniem wszystkich ludzi do zbawienia. Por. Międzynarodowa Komisja Teologiczna (dalej skrót: MKT), Chrześcijaństwo i religie (dalej skrót: ChR) 67-70, [w:] Od wiary do teologii. Dokumenty MKT 1969-1996, (red.) J. Króli k ow s ki, Wydawnictwo SCJ, Kraków 2000, s. 393-434. 
ta, jako sacramentum, communio salvifica i w konsekwencji, jako missio i communicatio królestwa Bożego wobec całego świata (por. Mt 28,19nn; Mk 16,15nn; Lk 24,46-49; Dz 1,8; J 20,21.23) ${ }^{36}$.

Definicja Kościola wypracowana przez Vaticanum II jest odzwierciedleniem nowego spojrzenia, w którym niezastąpiona rola Kościoła w procesie zbawienia zmieniła swoją optykę z „konieczności przynależenia do niego” na rzecz „konieczności jego powszechnej posługi zbawczej". Kościól, jako powszechny sakrament zbawienia, ma za zadanie służyć nadejściu królestwa Bożego, zjednoczeniu wszystkich ludzi z Bogiem oraz jedności ludzi między sobą ${ }^{37}$. Kościól staje się wobec tego nie tylko znakiem, ale i narzędziem królestwa Bożego, które przychodzi z mocą, a czyni to poprzez świadectwo, liturgię i służbę. W tych trzech określeniach objawia się zarówno misyjny charakter Kościoła ${ }^{38}$, jego powszechna celebracja Misterium Paschalnego ${ }^{39}$, jak i oddanie na rzecz budowania królestwa sprawiedliwości, miłości i pokoju ${ }^{40}$.

Powszechne królestwo Chrystusa jest otwarte na każdego czlowieka i pozostaje do jego dyspozycji jako droga prowadząca do pelni zbawienia. Takie przesłanie znajdujemy zarówno w samej postawie Jezusa, jak i w poslannictwie zleconemu swojemu Kościołowi. Głosić aż po krańce świata Dobrą Nowinę o zbawieniu oznacza przekraczać bariery przynależności kulturowej, rasowej, narodowej i religijnej ${ }^{41}$. Ze świadectw nowotestamentalnych warto w tym miejscu przytoczyć przede wszystkim rozmowę Jezusa z Samarytanką (por. J 4,1-26). Obraz ten jest szczególny pod względem zarówno samego przebiegu zdarzenia, jak i jego treściowego przesłania. Można powiedzieć, że ta scena stała się wzorem dla ewangelizacyjnej działalności Kościola, wypływającej z nakazu Chrystusa, by wszystkim glosić królestwo Boże. Dla Jezusa zbawcza wiara jest w zasięgu nawet obcych i pogan, działa ona pośród nich i stanowi zaproszenie do pełnego udziału w dobrach królestwa, którego On jest nie tylko zwiastunem, ale stanowi jego zbawcze uosobienie.

${ }^{36}$ Por. A. A m a to, Gesì il Signore. Saggio di cristologia, EDB Bologna 1999, s. 602.

${ }^{37}$ Por. KK 1.

${ }^{38}$ Por. DM 1-2.

${ }^{39}$ Por. KK 10.

${ }^{40}$ Por. ChR 74-79.

${ }^{41}$ Por. B. Skó ra i in. (red.), Misje po Soborze Watykańskim II, Płockie Wydawnictwo Diecezjalne, Plock 1981, s. 303. 
Głoszenie ewangelizacyjnego orędzia zostało podjęte przez Kościół, który zdaje sobie sprawę $\mathrm{z}$ tego, że nie jest ono dla niego czymś fakultatywnym, ale „zadaniem i obowiązkiem, nałożonym mu przez Pana Jezusa, ażeby ludzie mogli wierzyć i dostąpić zbawienia" ${ }^{\prime 2}$. Podobnie jak dla Jezusa naczelnym i najważniejszym tematem Jego posłannictwa było królestwo Boże, tak i dla Kościoła w jego misji ewangelizacyjnej „królestwo Boże trzeba uważać za coś absolutnego, a wszystko inne należy od niego uzależniać"*3. W ujęciu adhortacji Evangelii nuntiandi Pawła VI „królestwo" i „zbawienie" stają się pojęciami kluczowymi dla zrozumienia ewangelizacji Jezusa Chrystusa. Te dobra mają charakter powszechny i może otrzymać je każdy człowiek, który prowadzi życie według zasad Ewangelii, pracuje i cierpi, podejmuje swój krzyż w duchu ewangelicznych błogosławieństw oraz odnawia siebie poprzez przemianę swego ducha i serca ${ }^{44}$.

Wszyscy, którzy przyjmują Dobrą Nowinę, tworzą wspólnotę, która najpierw sama szuka królestwa, buduje je i wprowadza do swojego życia, by następnie stać się głosicielką Ewangelii. Polecenie Jezusa: „Idźcie i głoście Ewangelię”, dotyczy wszystkich chrześcijan, gdyż królestwo, które „przyszło i już się rozpoczęło, odnosi się do wszystkich ludzi wszystkich czasów" ".5. Kościół, używając słów św. Pawła, jest świadomy ciążącego na nim obowiązku i biada mu, gdyby nie głosił Ewangelii (por. 1Kor 9,16). Do jego natury należy więc ewangelizacja, czyli głoszenie i nauczanie słowa Bożego, poprzez które dochodzi do nas dar łaski. Wyraża się on w pojednaniu grzeszników z Bogiem oraz uobecnianiu ofiary Chrystusa w Eucharystii, będącej pamiątką Jego śmierci i zmartwychwstania ${ }^{46}$.

Warto pamiętać, że powszechne królestwo Boże przepowiadane przez Jezusa, jest całkowicie dziełem miłującego Boga, a więc nie jest efektem ludzkich planów, spekulacji czy wysiłków. Jego nadejście i ustanowienie nie zależy od ludzkiej działalności, ale stanowi dar ze strony Boga, który jest jego absolutnym Królem (por. Mt

${ }^{42}$ Paweł VI, Adhortacja o ewangelizacji w świecie wspótczesnym Evangelii nuntiandi, 5. [W:] S kór a B. i in. (red.), Misje po Soborze Watykańskim II, Płockie Wydawnictwo Diecezjalne, Płock 1981 (dalej skrót: EN).

${ }^{43}$ EN 8.

${ }^{4}$ Por. EN 10.

4. EN 13.

40 Por. K. Mülle r, Teologia misji. Wprowadzenie, Verbinum, Warszawa 1989, s. 95. 
21,43; Lk 12,32 ${ }^{47}$. Całkowita darmowość królestwa Bożego nie oznacza, że ludziom pozostaje jedynie rola pasywna. Jednym z podstawowych warunków przyjęcia królestwa jest własne nawrócenie dokonane $w$ wierze. To jest zasadniczy wymóg w budowaniu królestwa i sposób, by człowiek mógł w nim uczestniczyć w pełnym wymiarze. Nawrócenie i wiara, to innymi słowy, pozostawienie Bogu swobody działania tak, by spełniała się Jego wola. Jedynie taki sposób postępowania czlowieka przybliża go do królestwa Bożego ${ }^{48}$.

\section{Slużebna misja Kościola}

Encyklika Jana Pawła II Redemptoris missio, podejmując tematykę królestwa Bożego, przypomina, że jest ono nie tylko przedmiotem misji Jezusa Chrystusa, ale „zachodzi w Nim tożsamość pomiędzy posłaniem i posłanym, pomiędzy tym, co mówi, co czyni i kim jest (...)" ${ }^{\prime 49}$. Dokument podkreśla także znamiona i wymogi królestwa, wskazując na jego wymiar uniwersalny, na jego przeznaczenie dla wszystkich ludzi. Wyzwolenie i zbawienie ofiarowane człowiekowi poprzez królestwo Boże dociera do niego zarówno w jego wymiarze fizycznym, jak i w wymiarze duchowym. Pierwotny Kościół skupia swoje nauczanie na głoszeniu Jezusa Chrystusa zmartwychwstałego, z którym utożsamia się Jego królestwo. Treść kerygmatu Jezusa, a więc królestwo, łączy się z kerygmatem Apostołów, czyli głoszeniem wydarzenia Jezusa Chrystusa. Stąd te dwa orędzia wzajemnie się uzupełniają i wyjaśniają̧, stawiając Kościół w relacji wyjątkowej względem zarówno Jezusa, jak i głoszonego przez Niego królestwa. Jest to postawa służebna, oparta na przekazanej mu przez Jezusa pełni dóbr i środków zbawienia oraz szczególnej obecności Ducha Świętego, który mieszka w Kościele, ożywia go swymi darami i charyzmatami, uświęca i stale odnawia ${ }^{51}$.

Służba Kościoła względem królestwa Bożego przejawia się nade wszystko w jego przepowiadaniu wzywającym do nawrócenia za-

${ }^{17}$ Por. W. Kaspe r, Jezus Chrystus, dz. cyt., s. 77.

${ }^{48}$ Por. R. S ch nack e n burg, Il messaggio morale del Nuovo Testamento, t. 1, Brescia 1989, s. 43.

${ }_{49} \mathrm{~J}$ a n Paweł II, Encyklika o stałej aktualności poslania misyjnego Redemptoris missio, 13. [W:] Encykliki Ojca Świętego Jana Pawła II, t. I, Wydawnictwo św. Stanisława B. M. Archidiecezji Krakowskiej i Wydawnictwo M, Kraków 1996 (Dalej skrót: RM).

${ }^{50}$ Por. RM 15.

${ }^{51}$ Por. RM 18. 
równo pojedynczych osób, jak i całej ludzkiej społeczności. Podobnie jak w przepowiadaniu Jezusa, królestwo Boże w nauczaniu Kościoła jest blisko i wymaga od czlowieka nawrócenia, a w konsekwencji przemiany życia i pozytywnej odpowiedzi w postaci wiary i przyjęcia zasad ewangelicznych. Choć pełnia zbawienia zrealizuje się dopiero w wymiarze eschatologicznym, to rozpoczyna się ono już teraz w nowości życia w Chrystusie ${ }^{52}$. Do Niego więc, poznanego przez nauczanie Kościoła, wszyscy powinni się nawrócić i przez chrzest złączyć się z Nim oraz Kościolem, który jest Jego Ciałem. Konieczność wiary i chrztu na drodze poznania Boga i otwarcia się na rzeczywistość Jego królestwa (por. Mk 16,16; J 3,5) potwierdza jednocześnie konieczność Kościoła, do którego poprzez sakrament chrztu ludzie dostają się jak przez bramę ${ }^{53}$.

$\mathrm{Na}$ Kościele ciąży odpowiedzialność zapisana w nakazie misyjnym, by głosić Ewangelię wszelkiemu stworzeniu. I choć Bóg, wiadomymi sobie tylko drogami, może doprowadzić ludzi do zbawienia, Kościól jawi się na tej drodze jako warunek konieczny ze względu na swoje zakorzenienie w Trójcy Świętej i posiadanie pełni środków zbawienia. Służba Kościoła względem królestwa Bożego przejawia się w ukazywaniu Chrystusa głoszącego orędzie „nawracajcie się i wierzcie w Ewangelię", ze względu na bliskość królestwa. Chrystus staje się źródłem i wzorem odnowionej, przenikniętej duchem wzajemnej miłości, braterstwa i pokoju ludzkości. Chrystus i Kościól, który poprzez głoszenie Ewangelii daje o Nim świadectwo, stają ponad wszelkimi podziałami ludzkimi. Nikt nie może samego siebie wyzwolić z grzechu, osamotnienia i słabości, „wszyscy natomiast potrzebują Chrystusa jako wzoru, nauczyciela, wyzwoliciela, zbawiciela, ożywiciela"s4.

Kościół służy także królestwu poprzez zakładanie wspólnot chrześcijańskich i Kościołów lokalnych. W ten sposób prowadzi ludzi zgromadzonych wokół osoby Jezusa Chrystusa do dojrzewania w wierze i miłości. Dojrzałość ta przejawia się w otwarciu na innych, w służbie człowiekowi i społeczeństwu oraz zrozumieniu i poszanowaniu ludzkich instytucji. Ten wymiar służebnej roli Kościoła względem królestwa Bożego odzwierciedla społeczny cha-

\footnotetext{
${ }^{52}$ Por. RM 20

${ }^{53}$ Por. DM 7.

${ }^{54} \mathrm{DM} 8$.
} 
rakter zbawczego planu Boga względem człowieka. Temu ma służyć działalność Kościoła powolująca do życia nowe wspólnoty chrześcijańskie, które rodzą się nie z ciała, lecz z wody i Ducha Świętego (por. J 3,5-6). Tworzą one nowy Lud Boży, którego Głową jest Chrystus, wydany za nasze grzechy i zmartwychwstały dla naszego usprawiedliwienia (por. Rz 4,25). Lud ten cieszy się godnością i wolnością synów Bożych, w których sercach zamieszkuje Duch Święty. Prawem tego ludu jest przykazanie miłości, a celem „królestwo Boże, zapoczątkowane na ziemi przez samego Boga i mające się dalej rozszerzać, aż na końcu wieków dopełnione zostanie również przez Boga" 55 .

Choć ten nowy Lud Boży, którego wyrazem jest Kościół, w służbie królestwa nie obejmuje wszystkich ludzi, to jest on potężnym zalążkiem jedności, nadziei i zbawienia dla całego rodzaju ludzkiego. Kościół otwiera się na innych, służy człowiekowi i społeczeństwu, gdyż został ustanowiony dla wspólnoty życia, miłości i prawdy. Staje się prawdziwym narzędziem zbawienia dla wszystkich i posłany jest do calego świata. Do nowego Ludu Bożego powołani są wszyscy ludzie ze względu na zamiar woli Boga, który stworzył jedną naturę ludzką. „A ponieważ królestwo Chrystusowe nie jest z tego świata (por. J 18,36), przeto Kościól, czyli Lud Boży, wprowadzając to królestwo, nie przynosi żadnego uszczerbku dobru doczesnemu jakiegokolwiek narodu" ${ }^{\circ 6}$. Z tej zasady wynika również wysiłek Kościoła głoszącego królestwo Boże, by poprzez zaangażowanie ludzi świeckich nieść pomoc społeczno-gospodarczą narodom będącym na drodze rozwoju, zwlaszcza poprzez instytucje slużące podstawowym strukturom życia społecznego ${ }^{57}$.

Wyrazem służby Kościoła wobec królestwa są wartości ewangeliczne, które pomagają ludziom w przyjmowaniu Bożego planu zbawienia. Naturalną przestrzenią rozwijania się królestwa Bożego jest cała ludzkość, o ile żyje ona wartościami ewangelicznymi i otwiera się na działanie Ducha, który działa w sposób wolny i nieskrępowany, udzielając swego tchnienia (por. J 3,8). Kościół jest dla świata sakramentem zbawienia i nie może ograniczać się wyłącznie do tych, którzy przyjmują jego orędzie. Wspomniane warto-

\footnotetext{
${ }^{55} \mathrm{KK} 9$.

${ }^{56} \mathrm{KK} 13$.

${ }^{57}$ Por. DM 41.
} 
ści ewangeliczne przejawiają się w dialogu, ludzkim postępie, zaangażowaniu na rzecz sprawiedliwości i pokoju, w wychowaniu, opiece nad chorymi oraz pomocy dla ubogich i maluczkich. Zawsze mają one na uwadze jednak prymat wartości transcendentnych i duchowych, będących fundamentem zbawienia eschatologicznego ${ }^{58}$.

Szerzenie przez Kościół wartości ewangelicznych w perspektywie królestwa powinno dokonywać się poprzez świadectwo życia chrześcijańskiego ożywianego tą miłością, jaką umiłował nas Bóg. Ma ona obejmować wszystkich, bez względu na rasę, pochodzenie społeczne czy też religię i ma dokonywać się w sposób bezinteresowny. Chrystus obchodził miasta i wioski, uzdrawiając z wszelkich chorób i wyrzucając złe duchy na znak, że nadeszło już królestwo Boże. Podobnie Kościól przez swoje dzieci łączy się z ludźmi każdego stanu, zwłaszcza z biednymi i uciśnionymi, uczestniczy w ich radościach i cierpieniach, współczuje w ich śmiertelnych niepokojach. Posłannictwo Kościoła przyczynia się do wzrostu godności człowieka i braterskiej jedności, uczy prawd religijnych i moralnych, które Chrystus opromienił swym światłem. W Nim bowiem ukazał się nowy czlowiek, stworzony na obraz Boży, w którym miłość Boża objawiła się w sposób pełny ${ }^{59}$.

Analizując służebną misję Kościoła względem królestwa Jezusa Chrystusa, które pozostanie zawsze dziełem i darem Bożym, należy zwrócić także uwagę na wstawienniczy charakter wspólnoty kościelnej. Zarówno ewangeliczne przypowieści, jak i modlitwa, której nauczył ludzi Jezus Chrystus, wskazują na konieczność modlitwy-prośby, aby królestwo nadeszło. Trzeba je przyjąć i pozwolić mu wzrastać wśród ludzi, aż do momentu, gdy Chrystus „przekaże królowanie Bogu i Ojcu”, który będzie „wszystkim we wszystkich” (por. 1Kor 15,24.28) ${ }^{60}$. W ten sposób Kościół nie staje się celem sam w sobie, lecz ze wszystkich sił angażuje się, by cały należeć do Chrystusa i w Nim bez reszty służyć ludziom.

\section{Zakończenie}

Służebna rola Kościoła i jego znaczenie w głoszeniu królestwa Bożego stanowi dla współczesnego człowieka istotny element

\footnotetext{
${ }^{58}$ Por. RM 20.

${ }^{59}$ Por. DM 12.

${ }^{60}$ Por. RM 20.
} 
zbawczego działania Boga. To w Kościele bije trynitarne źródło zbawienia, które swoim powszechnym zasięgiem obejmuje wszystkich ludzi. Dzieje się to poprzez tajemnicze działanie Ducha Świętego, który będąc darem Ojca i Syna, przenika rzeczywistość stworzoną. On jest Panem i Ożywicielem, który kontynuuje dzieło zbawienia, gdyż wolą Bożą jest, aby wszyscy ludzie doszli do poznania prawdy. Kościól, mocą Jezusa Chrystusa, jako powszechny sakrament zbawienia, cały oddaje się na służbę człowiekowi w jego dążeniu do pełnego zjednoczenia z Trójcą Świętą. Wzywa więc wszystkich do nawrócenia, wskazując drogi powrotu do przyjaźni z Bogiem i szerzy wartości ewangeliczne, których podstawą jest miłość chrześcijańska. Stanowi ona odblask tej jedynej Miłości, której na imię Ojciec, Syn i Duch Święty.

\section{La Chiesa al servizio del regno di Dio.}

\section{L'aspetto trinitario ed ecclesiale della salvezza dell'uomo}

Lidea del regno di Dio sta al centro della missione di Gesù Cristo e rispecchia l'universalità del piano salvifico di cui la vera e unica sorgente si trova nella Santissima Trinità. La Chiesa continua a diffondere la buona notizia del „regno” e vede in esso lo scopo e la pienezza della missione ricevuta dal suo Fondatore. It regno di Dio proclamato dalla Chiesa porta all'uomo la salvezza che assume il carattere trinitario e si esprime nei diversi piani della sua vita e del suo ministero della Chiesa. â anche questo il vero ruolo della Chiesa oggi. Per rilevare il carattere trinitario ed ecclesiale della salvezza dell'uomo attraverso la missione della Chiesa si analizzano, con l'aiuto dei documenti del magisterio della seconda metà del XX secolo, i seguenti argomenti: 1. Radici trinitarie della Chiesa. 2. Missione trinitaria della Chiesa. 3. La relazione tra Gesù Cristo, il regno e la Chiesa. 4. La Chiesa come il sacramento univesale di salvezza. 5. Alcuni aspetti della missione della Chiesa di oggi nel contesto del regno di Dio. 